\title{
An Antibody Against the SecA Membrane Protein of One Phytoplasma Reacts with Those of Phylogenetically Different Phytoplasmas
}

\author{
Wei Wei, Shigeyuki Kakizawa, Hee-Young Jung, Shiho Suzuki, Minoru Tanaka, Hisashi Nishigawa, \\ Shin-ichi Miyata, Kenro Oshima, Masashi Ugaki, Tadaaki Hibi, and Shigetou Namba
}

First, ninth, tenth, and eleventh authors: Laboratory of Plant Pathology, Graduate School of Agricultural and Life Sciences, The University of Tokyo, 1-1-1 Yayoi, Bunkyo-ku, Tokyo 113-8657, Japan; second, third, fourth, and sixth to eleventh authors: Laboratory of Bioresource Technology, Graduate School of Frontier Sciences, The University of Tokyo, 202-Bioscience Building, 5-1-5 Kashiwanoha, Kashiwa, Chiba 277-8562, Japan; and fifth author: Department of Plant Protection, National Agriculture Research Center, Tsukuba 305-8666, Japan. Accepted for publication 25 February 2004.

\begin{abstract}
Wei, W., Kakizawa, S., Jung, H.-Y., Suzuki, S., Tanaka, M., Nishigawa, H., Miyata, S., Oshima, K., Ugaki, M., Hibi, T., and Namba, S. 2004. An antibody against the SecA membrane protein of one phytoplasma reacts with those of phylogenetically different phytoplasmas. Phytopathology 94:683-686.

Antisera raised against phloem-limited phytoplasmas generally react only with the phytoplasma strain used to produce the antigen. There is a need for an antiserum that reacts with a variety of phytoplasmas. Here,

we show that an antiserum raised against the SecA membrane protein of onion yellows phytoplasma, which belongs to the aster yellows $16 \mathrm{~S}$ group, detected eight phytoplasma strains from four distinct 16S-groups (aster yellows, western X, rice yellow dwarf, and elm yellows). In immunoblots, an $\approx 96-\mathrm{kDa}$ SecA protein was detected in plants infected with each of the eight phytoplasmas. Immunohistochemical staining of thin sections prepared from infected plants was localized in phloem tissues. This antiserum should be useful in the detection and histopathological analysis of a wide range of phytoplasmas.
\end{abstract}

The phytoplasmas are diverse, economically important, prokaryotic phytopathogens that are transmitted by insects, primarily leafhoppers. Like other mollicutes, phytoplasmas lack cell walls and reside endocellularly within insects and plant phloem $(16,20)$. Phytoplasmas cause more than 700 diseases in several hundred plant species, representing about 100 families $(16,19,22)$. Phylogenetic analysis of $16 \mathrm{~S}$ ribosomal DNA sequences indicates that phytoplasmas are most closely related to acholeplasmas, and are currently classified into $1016 \mathrm{~S}$-groups $(12,13,21,26)$.

Several techniques have been used to detect phytoplasmas, including polymerase chain reaction (PCR) (23), DNA hybridization (17), and electron microscopy (8), but each of these methods has inherent disadvantages. PCR and DNA hybridization require specialized equipment but do not offer histological views of the infected tissues. In contrast, serological detection using a specific antiserum is an economical and convenient method that allows for both analysis of many samples in a short time and immunohistological observation of infected tissues.

Phytoplasmas have not been cultured in vitro. The first antibody that recognizes phytoplasmas was produced in 1974, when a partially purified phytoplasma preparation was used as an immunogen (27). Since then, enriched or partially purified phytoplasma preparations from infected plants have been used to raise polyclonal and monoclonal antibodies against several phytoplasma isolates, including aster yellows (AY) (10), clover phyllody (CP) (11), primula yellows (7), grapevine flavescence dorée (3), maize bushy stunt (5), elm yellows (4), and ash yellows (6). However, this approach can result in polyclonal antibodies with insufficient titers, low specificity to the target phytoplasma, and

Corresponding author: S. Namba; E-mail address: snamba@ims.u-tokyo.ac.jp

Publication no. P-2004-0503-01R

(C) 2004 The American Phytopathological Society cross-reactivity with plant components. The application of monoclonal antibody technology has eliminated several of these problems, but monoclonal antibodies often react only with the original phytoplasma isolate used as the immunogen.

Recently, a novel strategy (14) including the following steps was reported: (i) cloning of the phytoplasma gene fragment into an Escherichia coli expression vector; (ii) expression in E. coli and purification of the protein; and (iii) preparation of antibodies in rabbit. This technique has been used to develop antibodies to the immunodominant membrane protein of several phytoplasmas including apple proliferation (AP) (1), CP, western X (WX) disease (2), and onion yellows (OY) (15). These antibodies represent important tools in the detection, localization, and purification of phytoplasmas and the target antigen. However, immunodominant membrane proteins from different strains usually have limited amino acid sequence identity, such that antibodies raised against each immunodominant membrane protein are generally strainspecific. Although an antiserum raised against the gyrase A protein of Acholeplasma laidlawii was reported to react with phytoplasmas of three different $16 \mathrm{~S}$-groups (18), it also reacts with acholeplasmas.

The SecA protein is one of only a few phytoplasmal membrane proteins for which a function has been determined. As a component of the Sec protein translocation system, SecA with its ATPase activity drives protein secretion in a stepwise manner (9). The Sec system is universally present in bacteria and is indispensable for cell viability. Amino acid sequence motifs are highly conserved among SecA proteins from widely ranging species of bacteria (14). Therefore, SecA is a viable candidate immunogen for the production of antibodies that react with many different phytoplasmas. We previously isolated and cloned the secA gene from the OY phytoplasma genome, prepared anti-SecA rabbit antibodies using a partially purified SecA protein that had been expressed in E. coli, and confirmed that the SecA protein is pro- 
duced in plants infected with OY phytoplasma (14). The aim of the present study was to evaluate the reactivity of different phytoplasmas with the antiserum raised against OY-SecA.

\section{MATERIALS AND METHODS}

Plant materials and phytoplasma isolates. Eight phytoplasma isolates of four distinct 16S-groups (13) were used in this study (Table 1). Five of the phytoplasmas were transmitted to periwinkle (Catharanthus roseus L.) and maintained therein using their insect vectors: water dropwort yellows (WDY), lettuce yellows (LeY), and adzuki yellows (AdY) by Macrosteles striifrons Anufriev; gentian witches' broom (GWB) by Scleroracus flavopictus Ishihara; and the jujube witches' broom (JWB) phytoplasmas by Hishimonoides sellatiformis Ishihara. Mulberry dwarf (MD) phytoplasma was transmitted by $H$. sellatiformis Ishihara and maintained in garland chrysanthemum (Chrysanthemum coronarium L.). MD-infected garland chrysanthemum and naturally infected mulberry (Morus alba L.) were used for immunohistochemical analysis and immunoblot analysis, respectively. Japanese hydrangea phyllody (JHP) and rice yellow dwarf (RYD) phytoplasmas were collected from naturally infected Japanese hydrangea (Hydrangea macrophylla Thunb.) and rice (Oryza sativa L.) host plants. In addition, OY phytoplasma was transmitted by $M$. striifrons to garland chrysanthemum and maintained therein. OY-infected garland chrysanthemum showing typical symptoms (yellowing, stunting, and virescence) was used as a positive control, and healthy garland chrysanthemum, mulberry, Japanese hydrangea, rice, and periwinkle were used as negative controls.

Immunoblot analysis. Leaves $(0.1 \mathrm{~g})$ of phytoplasma-infected plants and control plants were homogenized in $1 \mathrm{ml}$ of $2 \times$ sodium dodecyl sulfate (SDS) sample buffer (50 mM Tris-HCl, pH 6.8, $2 \%$ SDS, and $2 \%$ [wt/vol] mercaptoethanol), transferred to a tube, boiled in water for $5 \mathrm{~min}$, and centrifuged at $15,000 \mathrm{rpm}$ for $10 \mathrm{~min}$. The solubilized proteins present in the supernatant were separated on $8 \%$ (wt/vol) SDS-polyacrylamide gels using Laemmli buffer. Proteins were electroblotted from gels (Bio-Rad Laboratories, Hercules, CA) onto polyvinylidene difluoride membranes (Millipore Corp., Bedford, MA). Immunological detection of blotted proteins was performed as described previously (14). Membranes were blocked with TBST (20 mM Tris-HCl [pH 7.5], $150 \mathrm{mM} \mathrm{NaCl}$, and $0.1 \%$ Tween 20 [vol/vol] ) and incubated with $3 \mu \mathrm{g}$ of anti-SecA immunoglobulin $\mathrm{G}$ (IgG) per ml. After incubation with this primary antibody, the membranes were washed with TBST and incubated with a horseradish peroxidase-tagged secondary antibody (Amersham Bioscience, Piscataway, NJ) that had been diluted 1:5,000 in TBST. Reacted proteins were visualized with an enhanced chemiluminescence (ECL) Plus Kit (solution $\mathrm{A} /$ solution $\mathrm{B}=4: 1[\mathrm{vol} / \mathrm{vol}]$ ) according to the manufacturer's protocol (Amersham Bioscience).

TABLE 1. Classification status and host plant sources of phytoplasmas used in this study

\begin{tabular}{|c|c|c|c|}
\hline Name of phytoplasma & Acronym & $\begin{array}{l}\text { 16S-group/ } \\
\text { subgroup }^{\mathrm{a}}\end{array}$ & Plant material \\
\hline Water dropwort yellows & WDY & AY/AY & Periwinkle \\
\hline Lettuce yellows & LeY & AY/AY & Periwinkle \\
\hline Mulberry dwarf & MD & AY/AY & $\begin{array}{l}\text { Garland chrysanthemum/ } \\
\text { mulberry }\end{array}$ \\
\hline Onion yellows & $\mathrm{OY}$ & AY/AY & Garland chrysanthemum \\
\hline \multicolumn{4}{|l|}{ Japanese hydrangea } \\
\hline phyllody & JHP & AY/JHP & Japanese hydrangea \\
\hline Adzuki yellows & AdY & WX/WX & Periwinkle \\
\hline Gentian witches' broom & GWB & WX/WX & Periwinkle \\
\hline Rice yellow dwarf & RYD & RYD/RYD & Rice \\
\hline Jujube witches' broom & JWB & EY/JWB & Periwinkle \\
\hline
\end{tabular}

${ }^{a} \mathrm{AY}$, aster yellows; WX, western $\mathrm{X}$; and EY, elm yellows.
Immunohistochemical analysis. Immunohistochemical analysis of infected plants was carried out using anti-SecA IgG as described by Oshima et al. (24). A main stem or a root about $5 \mathrm{~mm}$ in length was excised from each phytoplasma-infected plant, fixed, embedded in paraffin, and cut into $8-\mu \mathrm{m}$ sections with a microtome. Anti-SecA IgG was allowed to react with the cross sections, and phytoplasma was detected with an alkaline-phosphatase reporter system according to the manufacturer's protocol (Promega, Madison, WI). To prevent rice root sections from floating off, the slides were treated with $2 \%$ (wt/vol) 3-aminopropyltriethoxysilane before use.

\section{RESULTS}

Immunoblot analysis. An antiserum raised against SecA of OY phytoplasma was evaluated for detection of different phytoplasmas. Crude protein preparations of WDY, LeY, MD and JHP (AY 16S-group), AdY and GWB (WX 16S-group), RYD (RYD 16S-group), and JWB phytoplasmas (EY 16S-group) were prepared from infected plants (Table 1) and separated on $8 \%(\mathrm{wt} / \mathrm{vol})$ SDS-polyacrylamide gel electrophoresis. Western blot analysis using the anti-SecA IgG revealed an abundant polypeptide in fractions prepared from phytoplasma-diseased plants (Fig. 1, lanes $1,3,5,7$, and 9 to 13) that was not present in the extracts of healthy plants (Fig. 1, lanes 2, 4, 6, 8, and 14). The estimated molecular weight of the detected polypeptides $(\approx 96 \mathrm{kDa})$ corresponded well with that of OY SecA $(95.7 \mathrm{kDa})$, as observed previously (14). In the JHP-diseased plant and RYD-diseased plant, a nonspecific polypeptide also was detected (Fig. 1, lanes 5 and 7), respectively.

Immunohistochemical analysis. To confirm that the anti-SecA antibody raised against SecA of OY phytoplasma also can be used to detect different phytoplasmas in diseased plants, and to compare their distribution patterns in the infected phloem cells, immunohistochemical localization of the detected protein was performed. Blue signals representing the SecA protein were detected in all phytoplasma-infected plants (Fig. 2A, B, D, F, and H), whereas no signal was detected in healthy plants (Fig. 2C, E, G, and I). Moreover, the SecA-specific signals were restricted to the phloem tissues (Fig. 2A, B, D, F, and H), where phytoplasmas are exclusively localized in plants $(17,19,22)$. Unlike garland chrysanthemum and Japanese hydrangea, periwinkle and rice have two distinct (internal and external) phloem tissues, and the phytoplasmas were observed in both (Fig. 2D and H).

Internal morphological changes also were observed in host plants infected with phytoplasmas. In OY-infected garland chrysanthemum, phloem hyperplasia and sieve-cell necrosis (Fig. 2A) (24) were apparent. Necrotic cells were misshapen and dark

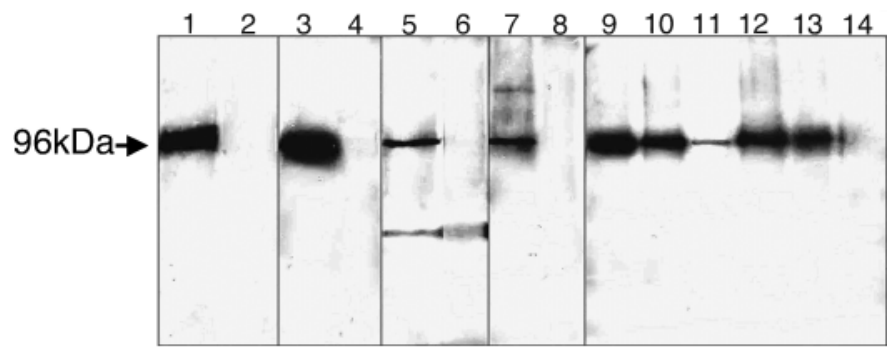

Fig. 1. Western immunoblot detection of the SecA protein in phytoplasmainfected plants using an anti-OY-SecA antiserum. Lane 1, garland chrysanthemum infected with onion yellows phytoplasma; lane 2, healthy garland chrysanthemum; lane 3, mulberry infected with mulberry dwarf phytoplasma; lane 4, healthy mulberry; lane 5, Japanese hydrangea infected with Japanese hydrangea phyllody phytoplasma; lane 6, healthy Japanese hydrangea; lane 7, rice infected with rice yellow dwarf phytoplasma; lane 8 , healthy rice; lanes 9 to 13 , periwinkle plants infected with water dropwort yellows, lettuce yellows, adzuki yellows, gentian witches' broom, and jujube witches' broom phytoplasma, respectively; and lane 14 , healthy periwinkle. 
brown, and no blue signal indicative of phytoplasmas was observed in these cells (Fig. 2A). In addition, vascular bundles lost their normal shape and the phloem tissues of vicinal vascular bundles were connected with each other, due to phloem hyperplasia (Fig. 2A). In contrast, in MD-infected garland chrysanthemum, no phloem hyperplasia or necrosis was observed (Fig. 2B), its internal symptoms were similar to those of garland chrysanthemum infected with OY-M, a variant derived from OY that causes only mild proliferation, mild leaf yellowing, and no stunting of the plant (24). Vascular bundles in RYD-infected rice were barely distinguishable from neighboring bundles, due to structural breakdown (Fig. 2H). No histopathological changes except for phloem necrosis were observed in periwinkles infected with WDY (Fig. 2D), LeY, AdY, GWB or JWB (data not shown), or in JHP-infected Japanese hydrangea (Fig. 2F).

\section{DISCUSSION}

An antiserum that detects multiple phytoplasma strains has long been needed. The antiserum raised against OY phytoplasma
SecA (14) is a plausible candidate to detect a wide range of phytoplasmas, because the SecA protein is unique to bacteria, archaea, and organelles (25), and the sequences of the OY SecA and the putative SecA of chloroplasts are not very similar (data not shown). Thus, this antiserum should result in low levels of background signals derived from plant or organelle components. Second, reaction of anti-SecA antiserum with OY phytoplasma-infected plant tissue resulted in a specific SecA signal in the phloem (14) where phytoplasmas reside. In this study, we have demonstrated that anti-OY SecA antibody raised against SecA protein of OY phytoplasma (AY 16S-group) can be used to specifically detect a wide range of phytoplasmas, including WDY, LeY, MD, and JHP (AY 16S-group), AdY and GWB (WX 16S-group), RYD (RYD 16S-group), and JWB (EY 16S-group).

Immunoblotting analysis with anti-OY SecA antibody indicated that a disease-specific polypeptide was detected in all phytoplasma-infected plants tested, but not in uninoculated healthy plants. The estimated molecular mass of the detected protein $(\approx 96 \mathrm{kDa})$ corresponds well with the calculated molecular weight of the OY SecA protein. This strongly suggests that the
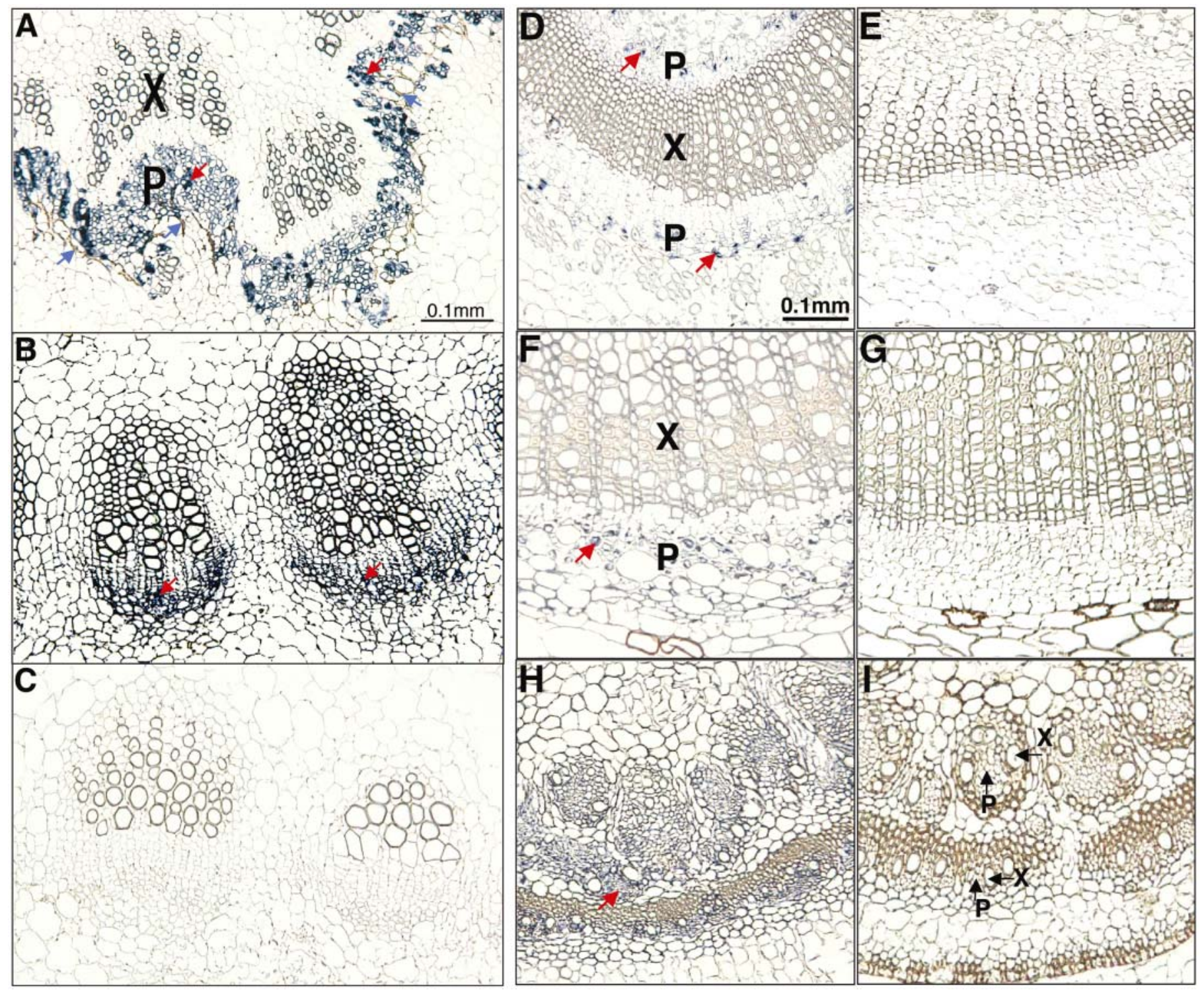

Fig. 2. Immunohistochemical detection of the SecA protein in cross sections of phytoplasma-infected plants. A and B, Garland chrysanthemum infected by onion yellows and mulberry dwarf phytoplasma, respectively; C, healthy garland chrysanthemum; D, periwinkle infected with water dropwort yellows (WDY); E, healthy periwinkle; F, Japanese hydrangea infected with Japanese hydrangea phyllody phytoplasma; G, healthy Japanese hydrangea; $\mathbf{H}$, rice infected with rice yellow dwarf phytoplasma; and I, healthy rice. The immunohistochemical results of periwinkle infected with WDY, lettuce yellows, adzuki yellows, gentian witches' broom, and jujube witches' broom phytoplasma were similar; therefore, here only one periwinkle sample (WDY-infected periwinkle) was shown. X, xylem; P, phloem. Scale bar $=0.1 \mathrm{~mm}$. Blue pigmentation represents the localization of the SecA protein. Blue arrowhead indicates necrotic cells. 
protein detected by the anti-OY SecA antibody was the SecA protein from each of the different phytoplasmas that was used to infect these plants.

Immunohistochemical analysis using the anti-SecA antibody revealed that specific signals were restricted to the phloem cells of the diseased plants. These data again strongly suggest that other phytoplasmas also synthesize SecA proteins that are specifically detectable by the anti-OY SecA antibody. Importantly, the intensities of the signals for the SecA proteins were almost identical among the different phytoplasmas, including the OY phytoplasma. This suggests that the epitope sequences of SecA proteins from different phytoplasmas are relatively conserved. In OY-infected garland chrysanthemum, no blue signal indicative of phytoplasmas was observed in necrotic phloem cells (Fig. 2A). This demonstrated that phytoplasma might not be present in these tissues, or that degradation of phytoplasmal proteins in these necrotic cells due to plant defensive reaction resulted in failure of signal detection.

The external and internal symptoms of host plants infected with phytoplasmas also were compared. Infection with the OY and MD phytoplasmas, which both belong to the AY 16S-group, resulted in different internal morphological changes in garland chrysanthemum (Fig. 2A and B), possibly due to differences in the pathogenicity of these phytoplasmas. Although a garland chrysanthemum plant infected with OY displayed typical external symptoms (yellowing, stunting, and proliferation) 4 weeks postinfection, a plant infected with MD only showed stunting without any other apparent symptoms. Internal differences also were evident in immunohistopathological analysis. However, in periwinkle plants infected through graft inoculation with the WDY (Fig. 1D), LeY, AdY, GWB, or JWB phytoplasmas (data not shown), rather than by insect transmission, only very mild histopathological changes were observed.

To our knowledge, the anti-SecA antiserum is the first phytoplasma-originated antiserum that can be used to detect a broad spectrum of phytoplasmas. This antiserum may be useful in the immunological detection of phytoplasmas. In addition, the use of the anti-SecA antiserum may facilitate the detection and identification of undiscovered phytoplasmas. Finally, the antiserum may aid in studies of the histopathological changes in infected host plants.

\section{ACKNOWLEDGMENTS}

We thank T. Shiomi, T. Usugi, M. Sato, N. Nishimura, T. Tsuchizaki, and S. Nakajima for discussion. This work was supported partly by Grants-in-Aid of Scientific Research from the Japan Society for the Promotion of Science (JSPS) (09460155 and 13306004) from the Ministry of Education, Culture, Sports, Science and Technology of Japan and by the Program for the Promotion of Basic Research Activities for Innovative Biosciences (PROBRAIN) of the Bio-oriented Technology Research Advancement Institution.

\section{LITERATURE CITED}

1. Berg, M., Davies, D. L., Clark, M. F., Vetten, H. J., Maier, G., Marcone, C., and Seemüller, E. 1999. Isolation of the gene encoding an immunodominant membrane protein of the apple proliferation phytoplasma and expression and characterization of the gene product. Microbiology 145:1937-1943.

2. Blomquist, C. L., Barbara, D. J., Davies, D. L., Clark, M. F., and Kirkpatrick, B. C. 2001. An immunodominant membrane protein gene from the Western X-disease phytoplasma is distinct from those of other phytoplasmas. Microbiology 147:571-580.

3. Boudon-Padieu, E., Larrue, J., and Caudwell, A. 1989. ELISA and dotblot detection of Flarescence dorée-MLO in individual leafhopper vectors during latency and inoculative state. Curr. Microbiol. 19:357-364.

4. Chang, T. I., and Chen, T. A. 1991. Utilization of monoclonal antibodies against elm yellows mycoplasma-like organisms in detection of elm yellow diseases. Phytopathology 81:121.

5. Chen, T. A., and Jiang, X. P. 1988. Monoclonal antibodies against the maize bushy stunt agent. Can. J. Microbiol. 34:6-11.

6. Chen, T. A., and Jiang, Y. P. 1990. Progress in the detection of plant mycoplasma-like organisms by using monoclonal and polyclonal antibodies. Zentralbl. Bakteriol. Suppl. 20:270-275.

7. Clark, M. F., Morten, A., and Buss, S. L. 1989. Preparation of mycoplasma immunogens from plants and a comparison of polyclonal and monoclonal antibodies made against primula yellows MLO-associated antigens. Ann. Appl. Biol. 114:111-124.

8. Doi, Y., Teranaka, M., Yoka, K., and Asuvama, H. 1967. Mycoplasma or P. L. T. group-like organisms found in the phloem elements of plants infected with mulberry dwarf, potato witches' broom, aster yellows or paulownia witches' broom. Ann. Phytopathol. Soc. Jpn. 33:259-256.

9. Economou, A. 1999. Following the leader: Bacterial protein export through the Sec pathway. Trends Microbiol. 7:315-320.

10. Errampalli, D., Fletcher, J., and Sherwood, J. L. 1989. Production of specific polyclonal antibodies against the aster yellows mycoplasma-like organisms (AY MLO) of Oklahoma. Phytopathology 79:1137.

11. Garnier, M., Iskra, G. M., Zreik, L., Gandar, J., Fos, A., and Bove, J. M. 1990. Monoclonal antibodies against the MLO associated with tomato stolbur and clover phyllody. Zentralbl. Bakteriol. Suppl. 20:263-269.

12. Jung, H.-Y., Sawayanagi, T., Kakizawa, S., Nishigawa, H., Miyata, S., Oshima, K., Ugaki, M., Lee, J.-T., Hibi, T., and Namba, S. 2002. 'Candidatus Phytoplasma castaneae', a novel phytoplasma taxon associated with chestnut witches' broom disease. Int. J. Syst. Evol. Microbiol. 52:15431549.

13. Jung, H.-Y., Sawayanagi, T., Wongkaew, P., Kakizawa, S., Nishigawa, H., Wei, W., Oshima, K., Miyata, S., Ugaki, M., Hibi, T., and Namba, S. 2003. 'Candidatus Phytoplasma oryzae', a novel phytoplasma taxon associated with rice yellow dwarf disease. Int. J. Syst. Evol. Microbiol. 53:1925-1929.

14. Kakizawa, S., Oshima, K., Kuboyama, T., Nishigawa, H., Jung, H.-Y., Sawayanagi, T., Tsuchizaki, T., Miyata, S., Ugaki, M., and Namba, S. 2001. Cloning and expression analysis of phytoplasma protein translocation genes. Mol. Plant-Microbe. Interact. 14:1043-1050.

15. Kakizawa, S., Oshima, K., Nishigawa, H., Jung, H. Y., Wei, W., Suzuki, S., Tanaka, M., Miyata, S., Ugaki, M., and Namba, S. 2004. Secretion of immunodominant membrane protein from onion yellows phytoplasma through the Sec protein-translocation system in Escherichia coli. Microbiology 150:135-142.

16. Kirkpatrick, B. C. 1992. Mycoplasma-like organisms: Plant and invertebrate pathogens. Pages 4050-4067 in: The Prokaryotes. A. Balows, H. G. Truper, M. Dworkin, W. Harder, and K. H. Schleifer, eds. SpringerVerlag, New York.

17. Kirkpatrick, B. C., Stenger, D. C., Morris, T. J., and Purcell, A. H. 1987. Cloning and detection of DNA from a nonculturable plant pathogenic mycoplasma-like organism. Science 238:197-200.

18. Koui, T., Natsuaki, T., and Okuda, S. 2002. Antiserum raised against gyrase A of Acholeplasma laidlawii reacts with phytoplasma proteins. FEMS Microbiol. Lett. 206:169-174.

19. Lee, I. M., and Davis, R. E. 1992. Mycoplasmas which infect plant and insects. Pages 379-390 in: Mycoplasmas: Molecular Biology and Pathogenesis. R. N. McElhaney, L. R. Finch, J. B. Baseman, and J. Maniloff, eds. American Society for Microbiology, Washington, D.C.

20. Lee, I. M., Davis, R. E., and Gundersen-Rindal, D. E. 2000. Phytoplasma: Phytopathogenic mollicutes. Annu. Rev. Microbiol. 54:221-255.

21. Lim, P.-O., and Sears, B. B. 1989. 16S rRNA sequence indicate that plant-pathogenic mycoplasmalike organisms are evolutionary distinct from anima mycoplasmas. J. Bacteriol.171:5901-5906.

22. McCoy, R. E., Caudwell, A., Chang, C. J., Chen, T. A., Chiykowski, L. N., Cousin, M. T., Dale De Leeuw, G. T. N., Golino, D. A., Hackett, K. J., Kirkpatrick, B. C., Marwitz, R., Petzold, H., Sinha, R. H., Sugiura, M., Whitcomb, R. F., Yang, I. L., Zhu, B. M., and Seemüller, E. 1989. Plant disease associated with mycoplasma-like organisms. Pages 546-640 in: The Mycoplasmas, Vol. 5: Plant Diseases Associated with MycoplasmaLike Organisms. R. F. Whitcomb and J. G. Tully, eds. Academic Press, New York.

23. Namba, S., Kato, S., Iwanami, S., Oyaizu, H., Shiozawa, S., and Tsuchizaki, T. 1993. Detection and differentiation of plant-pathogenic mycoplasmalike organisms using polymerase chain reaction. Phytopathology 83:786-791.

24. Oshima, K., Shiomi, T., Kuboyama, T., Sawayanagi, T., Nishigawa, H., Kakizawa, S., Miyata, S., Ugaki, M., and Namba, S. 2001. Isolation and characterization of derivative lines of the onion yellows phytoplasma that do not cause stunting or phloem hyperplasia. Phytopathology 91:10241029.

25. Pohlschröder, M., Prinz, W. A., Hartmann, E., and Beckwith, J. 1997. Protein translocation in the three domains of life: Variations on a theme. Cell 191:563-566.

26. Seemüller, E., Schneider, B., Maurer, R., Ahrens, U., Daire, X., Kison, H., Lorenz, K. H., Firrao, G., Avinent, L., and Sears, B. B. 1994. Phylogenetic classification of phytopathogenic mollicutes by sequence analysis of 16S ribosomal DNA. Int. J. Syst. Bacteriol. 44:440-446.

27. Sinha, R. C. 1974. Purification of mycoplasma-like organisms from China aster plants affected with clover phyllody. Phytopathology 64:1156-1158. 